УДК 340.15(477) +342.41(477)

Каніщев Г. Ю.

doi: $10.32620 /$ gch.2018.4.10

\title{
ЛОГІКА ВИКЛАДАННЯ ІСТОРІЇ ДЕРЖАВИ І ПРАВА УКРАЇНИ ВІДПОВІДНО ДО КОНСТИТУЦІї УКРАЇНИ
}

Статтю присвячено проблемам викладання історії держави $i$ права України в контексті статей Конституиї Украӥни, щчо відображають права громадян України в изарині ідеології, свободи слова, поглядів і переконань.

Ключові слова: ідеологія, ідеологічна багатоманітність, погляди й переконання.

The article deals with the problems of teaching history of State and Law in the context of the articles of the Constitution of Ukraine that depict the rights of citizens of Ukraine in the sphere of ideology, freedom of speech, opinion and beliefs.

Keywords: ideology, ideological diversity, views and beliefs.

Статья посвящена проблемам преподавания истории государства и права Украинь в контексте статей Конституции Украины, отображающих права граждан Украинь в области идеологии, свободь слова, взглядов и убеждений.

Ключевые слова: идеология, идеологическое многообразие, взгляды и убеждения.

Формулювання проблеми. Історію держави і права України можна вважати однією 3 провідних навчальних дисциплін для сучасних юристів, адже їі метою $\epsilon$ ознайомлення майбутніх фахівців із тим історичним досвідом розвитку державності та права на території сучасної України, що прямо або опосередковано впливає й на сучасний стан і якість публічної влади в нашій державі, на відносини між державою й громадянами, на становище України на міжнародній арені, iї імідж у світі тощо.

Велике значення для викладання та вивчення історії держави і права України мають зміни, які останнім часом відбуваються у вищій правовій освіті в нашій державі. Ідеться про потребу для сучасних i майбутніх юристів на додаток до необхідних юридичних навичок і знань розуміти природу права та філософію прав людини, роль бюрократії у функціонуванні державно організованого суспільства, механізм розподілу публічної влади, а також розуміти шляхи розвитку держави та іï переходу від держави, що розвивається, до розвиненої держави [15, с. 9]. Роль історії держави і права України тут полягає у відображенні процесів історичної еволюції взаємовідносин людини й держави на сучасній українській території. Це стосується дотримання державою прав громадян, зокрема політичних, боротьби людей за свої права як мирним, так i насильницьким шляхом (через збройне повстання проти державної влади) тощо. Велике значення у зв'язку із цим, на нашу думку, має відображення в навчальних курсах і наукових дослідженнях з історії держави і права України еволюції публічної влади внаслідок боротьби людей за свої права.

Усе це $є$ фактично новою метою вивчення дисципліни майбутніми фахівцями, адже дотепер головна увага у відповідних навчальних курсах приділялася не 
взаєминам людини й держави, а діяльності установ і посадових осіб публічної влади. Під останньою йшлося саме про державну владу (складовою невід'ємною частиною якої вважалося місцеве самоврядування).

Виконання історією держави і права України всіх цих завдань, докорінна перебудова іiі викладання відповідно до потреб часу, на нашу думку, потребують опори на Основний Закон нашої держави - Конституцію України. Законодавство України про вищу освіту, відповідно до пункту 1 статті 2 Закону України № 1556-VII «Про вищу освіту» від 1 липня 2014 року, грунтується саме на Конституції України [13]. Важливим у цьому плані є, на нашу думку, й Указ Президента України № 91 / 2018 «Про відзначення 22-ї річниці Конституції України» від 28 березня 2018 року. Тут, зокрема, ідеться про «проведення ... патріотично-виховних заходів, спрямованих на роз'яснення значення норм Конституції України в утвердженні правової держави, на формування правової культури, виховання громадянської свідомості та поваги до Основного Закону України, поширення знань про історію конституціоналізму» [12]. Усі ці моменти, особливо історія конституціоналізму в України, і $є$ предметом викладання для історії держави і права України.

Mema cmammi - проаналізувати положення Конституції України, які стосуються викладання історії держави і права України. Завдання статті - охарактеризувати основні, «вузлові» проблеми викладання історії держави і права України відповідно до Конституції України.

Аналіз останніх досліджень $і$ публікацій за темою. Відправною точкою для наших міркувань будуть служити терміни «Конституція» й «жива конституція». Так, відповідно до науково-практичного коментаря до Конституції України (стаття 8), підготовленого харківськими фахівцями під керівництвом В.Я. Тація, термін «Конституція» повинен позначати не «основний закон держави», а суспільний договір у вигляді основоположного акта, котрий становить єдино можливу легітимність самої держави як наслідковий інститут установчої влади народу [16]. Таке твердження, за словами авторів, випливає 3 доктрини природного права. Остання «є джерелом розуміння того, що права людини і основоположні свободи - це не надані державою своїм громадянам права у вигляді створених нею норм права, котрі містяться у законах держави, а що це - природні права, властиві людині від природи і які належать їй як творінню Природи, а не як члену суспільства» [16]. Отже, тут простежується тенденція протиставити поняття «Основний Закон» поняттю «Конституція».

На це зауважимо, що, по-перше, у тексті Конституції України, а саме, у іï преамбулі, ці два поняття є синонімами: «Верховна Рада України ...приймає цю Конституцію - Основний Закон України» [9]. По-друге, вважаємо, що від визначення Конституції України як Основного Закону природні права українців зовсім не постраждають. Адже сам текст Конституції починається словами: «Верховна Рада України від імені (виділене нами - Г. К.) Українського народу...» [9]. Це означає, що, ухвалюючи Конституцію України, Верховна Рада виражала суверенну волю українського народу, а не свою волю як органу законодавчої влади [2]. I саме народ $\epsilon$ первинним суб'єктом конституційних правовідносин, у яких обов'язковою стороною 
виступають українська держава, її органи та посадові особи [3].

У зв'язку з цим надзвичайно важливою видається нам думка, що в Конституції України «закріплені істотні умови своєрідного конституційного, публічного договору між державою в особі Верховної Ради України та громадянським суспільством, Українським народом» [2]. Приєднуємося до думки, що Конституція України $є$ договором між громадянами й державою. Це означає, що держава, як одна 3 договірних сторін, поряд 3 українським народом, бере на себе обов'язок дотримуватися прав людини й громадянина. А легітимність державної влади є прямо залежною від іiі діяльності щодо дотримання прав і свобод громадян. Це наше визначення підтверджується статтею 3 Конституції України: «Права і свободи людини та їх гарантії визначають зміст і спрямованість діяльності держави. Держава відповідає перед людиною за свою діяльність» [9].

У зв'язку з цим звертаємо увагу на коментар статті 8 Конституції України авторського колективу під керівництвом О.В. Петришина стосовно вищої юридичної сили Конституції України: «В Україні немає суб'єктів, котрим би дозволялося не дотримуватися іiі (Конституції України - Г. К.) положень» [11]. Це означає, що хоча Конституція України і є Основним Законом держави (i у цьому сенсі явищем позитивного, а не природного права), це зовсім не ставить державу Україна в особі іiі очільників та установ над конституційними нормами. Адже, відповідно до статті 19 Конституції України, «...органи державної влади та органи місцевого самоврядування, їх посадові особи зобов'язані діяти лише на підставі, в межах повноважень та у спосіб, що передбачені Конституцією та законами України» [9]. Причому, відповідно до статті 8 Конституції України, «...закони та інші нормативноправові акти приймаються на основі Конституції України і повинні відповідати їй» [9]. Це, своєю чергою, означає, що «кожен зобов'язаний неухильно дотримуватися... законів України» лише у тому разі, якщо вони відповідають Конституції України.

Визначившись таким чином із терміном «Конституція», перейдемо до терміна «жива конституція». Це поняття є запозиченням 3 американського конституційного права, де воно позначає тлумачення Конституції США (насамперед Верховним Судом цієї країни) з метою пристосування конституційних норм до потреб сьогодення й майбутнього [6].

В Україні термін «жива конституція» теж намагаються вживати саме в «американському» значенні, тобто як тлумачення Конституції України насамперед Конституційним Судом України відповідно до статті 147 Конституції України [9]. Не заперечуючи цього, зазначимо два моменти. По-перше, Конституція України на нашу думку, багато в чому є механічним переносом на український грунт правових норм Західного світу, погано пристосованих як до вітчизняних історичних і політичних реалій, так і до психології українців. По-друге, на відміну від США та інших західних держав 3 їх традиціями шанобливого ставлення до Основного Закону, Україна всі роки після ухвалення своєї Конституції на кожному кроці давала приклади нехтування нею як з боку звичайних громадян, так i, дуже важливо, з боку установ $\mathrm{i}$ посадових осіб публічної влади (держави й місцевого самоврядування).

Усе це означає, що потреба в тлумаченні Конституції в нашій країні є набагато 
ширшою, ніж тлумачення Основного Закону держави Конституційним судом (чи взагалі якоюсь публічно-владною установою й особою). В Україні для дотримання конституційного порядку й дійсно шанобливого ставлення до Основного Закону держави, для захисту громадянами своїх прав перед владою потрібним $є$ обов'язкове ознайомлення 3 текстом Конституції й право вільного іiі тлумачення кожним громадянином України. Це і є, вважаємо, «жива конституція» в українському варіанті цього терміна. Право кожного знати й вільно тлумачити Конституцію України зазначене, на нашу думку, у статті 57 Основного Закону України: «Кожному гарантується право знати свої права і обов'язки» [9]. Знання, як відомо, передбачає й осмислення змісту будь-якої інформації, у цьому випадку тексту Конституції України. Своєю чергою, осмислення означає вироблення власної думки щодо змісту конституційних норм та їх застосування у реальному житті, а також розповсюдження цієї думки серед інших людей на підставі статті 34 Конституції України, про яку йтиметься далі.

Зауважимо, що відповідно до статті 8 Основного Закону України, «норми Конституції України є нормами прямої дії» [9]. Це означає можливість (i необхідність) їх безпосереднього застосування, незважаючи на будь-які закони, а значить, знання і вміння тлумачити Конституцію держави для захисту своїх прав $\epsilon$ принципово важливими для громадян.

Виклад основного матеріалу. Викладання історії держави і права України стосується права на освіту, визначеного статтею 53 Конституції України [9]. Одним із фундаментальних положень цього права є релігійні й філософські переконання [16]. Це означає, що мета освіти, зокрема вищої, не лише надання визначеної суми знань, а й формування поглядів на ту чи іншу проблему, що розглядається під час освітнього процесу. Такі переконання формуються, як правило, «на об'єктивній, науковій основі без пропагандистських спрямувань» [16]. Саме це й покладається на державу в процесі освіти [16]. Відповідно викладання історії держави і права України повинно бути позбавлене пропагандистських штампів і грунтуватися виключно на принципі пошуку наукової істини.

Це наше твердження знаходить подальшу опору в статті 15 Конституції України: «Суспільне життя в Україні грунтується на засадах політичної, економічної та ідеологічної багатоманітності. Жодна ідеологія не може визнаватися державою як обов'язкова. Цензура заборонена. Держава гарантує свободу політичної діяльності, не забороненої Конституцією і законами України» [9]. За словами фахівців коментаторів цієї статті Основного Закону, «...ідеологічний плюралізм... знаходить відображення у політичній багатоманітності... Принцип політичної багатоманітності (політичний плюралізм) означає можливість існування різних поглядів на політичні проблеми розвитку держави та суспільства... Головним призначенням політичного плюралізму $є$ виявлення різноманітних політичних поглядів, ідей, концепцій, їх конкуренція в атмосфері демократичних дискусій 3 метою пошуків істини, досягнення на їі основі прийнятних компромісних рішень задля забезпечення єдності та ефективного розвитку суспільства» [16]. Це означає, що викладання історії держави і права України мусить грунтуватися на беззаперечному визнанні за всіма 
учасниками освітнього процесу - студентами й викладачами - права на власне трактування історичних явищ, пов'язаних з українською державністю та правом, не дотримуючись якихось «загальнообов'язкових» поглядів, оскільки, відповідно до Конституції України, таких поглядів просто не повинно бути.

Саме така різноманітність i, безумовно, суперечливість думок, вважаємо, і $є$ запорукою «...забезпечення єдності та ефективного розвитку суспільства», адже кінцевою метою висловлення різних і суперечливих думок $є$, як зазначалося вище, «досягнення ...прийнятних компромісних рішень». Компроміс - це думка (або думки), які влаштовують усіх або більшість учасників обговорення (дискусії) під час занять, хоча останні при цьому можуть (і мають на це право) залишитися при своїх думках. Це не суперечить поняттю «компроміс», однак компромісна думка, вироблена в процесі навчання, є, вважаємо, найбільш міцною, надійною запорукою того, що прихильники різних думок подолають конфлікт (або принаймні, не поглиблюватимуть його).

На противагу цьому одна «єдино правильна» думка, що, як правило, спускається «згори», не тільки не здатна, вважаємо, забезпечити єдність та ефективний розвиток суспільства, а й навпаки, сіє в ньому розбрат і ворожнечу і тим самим прямо руйнує його єдність. Зауважимо, що суперечки й конфлікти, які починаються під час занять в університетських аудиторіях, згодом часто переходять у більш масштабні й грізні конфлікти вже «на Майдані».

Саме тому приєднуємося до думки коментаторів цієї статті Основного Закону: «...Держава не може примушувати громадян, політичні партії чи громадські організації під загрозою кримінального переслідування обов'язково дотримуватися певних ідей, вивчати чи пропагувати будь-яку ідеологію. Конституційний принцип, відповідно до якого ніяка ідеологія не може встановлюватися як державна, закріплює рівноправність різних ідеологій у суспільстві. У демократичній державі жодна 3 них не може мати пріоритету перед іншими, підтримуватися офіційно державою за допомогою законодавчого закріплення чи в інший офіційний спосіб» [16]. Усі такі закони й підзаконні акти 3 погляду права $\epsilon$ недійсними, оскільки суперечать Конституції України, адже вони звужують й навіть фактично скасовують зміст та обсяг існуючих прав і свобод. Конституція України у статті 22 не допускає ні скасування, ні навіть звуження конституційних прав і свобод громадян, зокрема при ухваленні нових законів або внесенні змін до чинного законодавства [9]. Громадяни України у таких випадках мають застосовувати статтю 55 Конституції: «Кожен має право будь-якими не забороненими законом способами захищати свої права і свободи від порушень і протиправних посягань» [9], зокрема й з боку держави.

Це право в Основному Законі нашої держави підкріплюється правом на свободу думки й слова, на вільне вираження своїх поглядів і переконань, відображеним у статті 34 Конституції України [9]. Воно належить до групи природних прав людини й визнається не лише в теорії конституційного права, а й у цілому ряді міжнародних нормативно-правових актів [16]. «Свобода думки означає насамперед свободу у виборі ...своїх власних переконань, які виражаються у зовнішній формі. Таким чином, людину не можна примусити думати в той чи інший спосіб і будь-яка держава 
не повинна ставити перед собою подібну мету» [16]. Для викладання історії держави і права України ця стаття Основного Закону має наступне значення: кожен учасник освітнього процесу - викладач або студент - має право на вільне висловлювання своїх поглядів і дискусії під час занять.

Таким чином, обидві статті - 15-а і 34-а - є фундаментальними щодо процесу й змісту викладання історії держави і права України. Перша 3 них гарантує право студентів і викладачів на власне бачення історичних явищ, пов'язаних з українською державністю та правом i, відповідно, забороняє владі нав'язувати громадянам ідеологічні орієнтири у формі обов'язкової для всіх державної ідеології. Друга ж $\epsilon$ гарантією вільного публічного висловлення й відстоювання всіма учасниками освітнього процесу своїх поглядів і переконань щодо історичної еволюції держави і права України.

Заперечення Конституцією можливості визнання будь-якої ідеології як державної не означає, що в сучасному суспільстві не можуть існувати й розвиватися певні ідеологічні орієнтири [16], адже без них український народ просто не відбудеться як політична (громадянська) нація, а українська держава розвалиться. Відповідаючи на питання щодо змісту такої ідеології, звернемося до Закону України № 1556-VII «Про вищу освіту» від 1 липня 2014 р. [13]. Тут важливим є, на нашу думку, пункт 1 статті 2, де зазначається, що «законодавство України про вищу освіту базується на Конституції України [13]. Коментуючи цей пункт, зазначимо, що він означає прийняття українською державою на себе зобов'язання здійснювати контроль не тільки за дотриманням конституційних норм у закладах вищої освіти під час освітнього процесу (маємо на увазі дотримання прав студентів і викладачів), а й за впровадженням в освітній процес самих цих норм, перетворенням їх на ідеологічну основу викладання, у першу чергу в блоці соціальних і гуманітарних дисциплін. Більш конкретно про це йдеться у пункті 3 статті 58 Закону: тут йдеться про обов'язок науково-педагогічних працівників, тобто викладачів університету, прищеплювати особам, що навчаються, «любов до України, виховувати їх у дусі українського патріотизму і поваги до Конституції України (виділене нами - Г. К.) і державних символів України» [13].

Коментуючи цей пункт, зазначимо, що поряд із абстрактними поняттями «любові до України» та «українського патріотизму» він містить і конкретику, а саме поняття «Конституція України» й «державні символи України». Це означає, що ідеологією українського суспільства й держави повинні бути повага й дотримання Конституції України як Основного Закону, що визначає фундаментальні принципи їхного існування.

3’ясувавши, так би мовити, «загальні правила», на яких, вважаємо, повинно грунтуватися викладання історії держави і права України, перейдемо до наступної частини дослідження, а саме до тих місць у тексті Конституції, які безпосередньо стосуються історії української державності. Для цього перш за все звернемося до вступної частини (преамбули) Конституції України. Тут орієнтиром є насамперед абзац 3, де зазначається, що Верховна Рада України ухвалює Конституцію України, «спираючись на багатовікову історію українського державотворення» [9]. Це $\epsilon$, 
вважаємо, дуже важливим аспектом зв'язку між Конституцією України та історією української державності. До сих пір цей зв'язок у нашому дослідженні був, так би мовити, «однобічним», тобто історія держави і права України (точніше, іії викладання) грунтувалися на Конституції України. Тепер же простежується й зворотній зв'язок, а саме: Конституція України (і сама українська державність як така) грунтуються на історії українського державотворення і права.

Слід зазначити, що Конституція України у своїй преамбулі не містить конкретних вказівок на те, які державні утворення минулого слід вважати українськими. Такий розділ міститься, наприклад, у Конституції Республіки Хорватія від 22 грудня 1990 р. [10]. Тут міститься доволі довгий перелік державних утворень хорватського народу, починаючи від раннього Середньовіччя до кінця ХХ ст., об’єднаний спеціальним розділом «Історичні основи» [10]. Немає в преамбулі Конституції України й опосередкованої вказівки на конкретні традиції державності у вигляді, наприклад, переліку історичних земель (регіонів), із яких складається територія країни, як це зроблено в Конституції Латвійської Республіки від 15 лютого 1922 р. (відновлена 6 липня 199 р.). Тут у розділі 1 «Загальні засади» (він $є$ й у Конституції України) у пункті 3 зазначається: «Територію держави Латвії, у межах, встановлених міжнародними договорами, складають Відземе, Латгалє, Курземе і Зємгалє» (тут переклад автора - Г. К.)[8].

Відсутність таких уточнень у преамбулі української Конституції робить можливим і необхідним ii тлумачення щодо того, які саме державні утворення слід мати на увазі під «багатовіковою історією українського державотворення». I тут орієнтиром, вважаємо, повинні бути слова, із яких починається преамбула Конституції, а саме: «Верховна Рада України від імені Українського народу громадян України всіх національностей...» (виділене нами - Г. К.). Таке визначення українського народу одноголосно тлумачиться фахівцями-юристами як політична, а не етнічна нація, спільнота всіх громадян України [16]. «Фактично йдеться (в абзаці 3 преамбули Конституції України - Г. К.) про реалізацію політичного принципу, на якому заснована українська державність - єдності етнічних українських земель. ...Історично Україна склалася як союз народу України, шануючи національні інтереси інших народів» [3]. Зауважимо, що визначення українського народу саме як громадян України всіх національностей повністю відповідає, на нашу думку, тлумаченню Конституції України як договору. На цей раз - договору між українською нацією (етнічними українцями) і корінними народами та національними меншинами - відповідно до статті 11 Конституції України [9]. Предмет договору зазначений у преамбулі Конституції: це утворення спільної держави України на основі «здійсненого українською нацією, усім Українським народом права на самовизначення» [9]. Умови договору прописані в 11-й статті Конституції. Це обов'язок української держави сприяти, з одного боку, «консолідації та розвиткові української нації, іiі історичної свідомості, традицій і культури», а 3 другого «розвиткові етнічної, культурної, мовної та релігійної самобутності всіх корінних народів і національних меншин України» [9].

Яким повинен бути зміст викладання історії держави і права України, щоб 
відповідати згаданим вище умовам договору - Конституції України? Відповідаючи на це питання стверджуємо, що «багатовікова історія українського державотворення» (а значить, об'єкт дослідження і викладання для історії держави і права України) - це історія всіх держав на території сучасної України від давньої Скіфії та античних держав Північного Причорномор'я до СРСР - УРСР включно. Причому, ураховуючи неоднозначність, «розмитість» самого терміна «держава» протягом історії людства, стверджуємо, що сюди слід зарахувати не тільки «суверенні» держави в сучасному розумінні цього терміну, а й «несуверенні», «васальні» адміністративно-територіальні утворення з більшим або меншим рівнем автономії у складі інших держав [4, с. 89].

Відповідно, з історичного погляду, Україна є спадкоємицею всіх держав, які до 1991 р. були на iï території [7, с. 49]. Це твердження підкріплюємо наступною цитатою: «Головною особливістю історії держави і права України є те, що, досліджуючи історичну еволюцію української державності і права, вона обов'язково повинна враховувати геополітичний, релігійний, соціокультурний, а також правовий вплив, що виходив від наймогутніших держав, як існували навколо українських територій та нерідко інкорпорували їх до свого складу. Достатньо назвати такі держави, як Велике князівство Литовське, Польське королівство, Річ Посполита, Російська імперія, Австро-Угорщина тощо, щоб переконатися у вищевказаному твердженні» [4, с. 5]. Вищенаведений погляд можна схарактеризувати як концепцію «багатодержавності українського народу».

Сформульоване вище визначення багатовікової історії українського державотворення допомагає, на нашу думку, вирішенню трьох ключових проблем дослідження й викладання історії держави і права України: а) бездержавності української нації; б) історії держави і права України як частини всесвітньоісторичного процесу розвитку держави і права; в) історії держави і права України як основи для теоретичних узагальнень в галузі державності та права (у навчальному курсі «Теорія держави і права»).

Проблема бездержавності української нації полягає в пропагуванні, у першу чергу, в історичній та історико-правовій літературі, а також у публіцистиці, ідеї відсутності в українців (причому під українцями мається на увазі саме український етнос) власної незалежної держави протягом досить великого історичного періоду. Ми категорично заперечуємо цю ідею як таку, що суперечить Конституції України, а саме ідеї багатовікової історії українського державотворення. Натомість стверджуємо, що український народ (громадяни України всіх національностей) був державноорганізованим народом завжди, без переривання своєї державотворчої традиції. Інша справа, що їхня державність не завжди була «своєю», тобто утвореною власне українцями. Часто це були інші держави, які, як уже зазначалося вище, розповсюджували свою владу на всю або на окремі частини території сучасної України. Утім, для української нації це пом'якшувалося наступними обставинами. По-перше, вона часто зберігала всередині цих країн свою державність на засадах федерації або автономії як форм реалізації права нації на самовизначення [17, с. 397398]. Наприклад, у формі Української РСР. По-друге, українці брали участь, часом дуже активну, в управлінні цими державами. Особливо це стосується Російської 
імперії і Радянського Союзу. Тим більше, що формально, тобто 3 юридичного погляду, Україна є правонаступницею СРСР - УРСР відповідно до Закону України № 1543-XII «Про правонаступництво України» від 12 вересня 1991 р. [14].

Саме такий погляд на зміст викладання історії держави і права України, на нашу думку, повністю відповідає Конституції нашої держави, розвиває й конкретизує основні ії положення, визначені в преамбулі Основного Закону України.

Що ж стосується бездержавності, то це явище в історії держави і права України також мало місце. Однак, вважаємо, зовсім не в тому вигляді, як це прийнято традиційно сприймати. Приєднуємося до думки, що терміном «бездержавність (бездержав'я, недержавність)» слід позначати два явища. По-перше, стан суспільства, який характеризується відсутністю державних інституцій як таких. Такий стан був характерний для первіснообщинного ладу. По-друге, терміном «бездержавність», вважаємо, слід позначати стан хаосу, безладу й безвладдя, що виникає внаслідок воєн, повстань тощо [1]. Утім, така ситуація не означала тривалого стану бездержавності, адже внаслідок вищезгаданих потрясінь одна форма державності заміщалася іншою. I хоча держави минулого, зокрема на території України, були недосконалими порівняно із сучасною державністю, вони значно прискорювали прогрес цивілізації порівняно з бездержавним періодом історії людства.

Тлумачення багатовікової історії українського державотворення як історії всіх держав на території сучасної України, своєю чергою, пов'язує історію держави i права України з історією держави і права зарубіжних країн, робить ï органічною частиною всесвітньо-історичного процесу державотворення. Історія держави і права України в такому випадку перестає бути заідеологізованою, «поза простором i часом», навчальною дисципліною. Саме так, на нашу думку, виникає можливість робити узагальнення в галузі теорії держави і права не тільки на матеріалі історії держави і права зарубіжних країн (як це зазвичай робиться), а й на матеріалі історії держави і права України. Вважаємо, що для українських студентів така інформація буде значно більш цікавою й актуальною, ніж приклади 3 історії зарубіжного державотворення, не пов'язані (або мало пов'язані) з Україною.

Висновки з иього дослідження й перспективи подальших розвідок у цьвому напрямі:

1. Викладання історії держави і права України як навчальної дисципліни повинне відповідати Конституції України як Основному Закону держави та орієнтиру для суспільної діяльності.

2. Конституція України за своїм правовим характером є договором. По-перше, вона $\epsilon$ договором між українцями етнічних українських земель (усередині української нації), а також між українською нацією та іншими національностями (корінними народами й національними меншинами) України щодо об'єднання їх усіх в єдину українську державу. Ї̈̈ громадяни всіх національностей складають єдиний український народ.

По-друге, Конституція України є договором між українським народом та державою Україна (в особі Верховної Ради України) щодо ухвалення Конституції України, у першу чергу, для забезпечення прав і свобод людини [К. У., с. 3]. 
3. Кожна людина й громадянин України належить до суб'єктів вищезгаданого договору i, відповідно, має право знати й тлумачити текст договору - Конституцію України (концепція «живої конституції»).

4. Відповідно до концепції «живої конституції», багатовікова історія українського державотворення (яка $\epsilon$ основою викладання історії держави і права України) є історією всіх без винятку держав на сучасній території України до 1991 p. Усі такі держави слід вважати історичними державами українського народу, оскільки він брав участь, часом дуже активну, в управлінні ними (концепція «багатодержавності Українського народу»).

Відповідно, під «бездержавністю українського народу» слід розуміти лише повну відсутність державних інституцій у додержавний період, а також тимчасове припинення діяльності установ і посадових осіб держави під час масових повстань $\mathrm{i}$ воєн.

5. Правовими гарантіями наведених вище тлумачень та їх упровадження у викладання історії держави і права України є наступні норми Конституції України: ідеологічна багатоманітність, відсутність обов'язкової державної ідеології, заборона цензури, свобода думки й слова, вільного вираження своїх поглядів і переконань.

Напрямки подальших досліджень у цьому напрямку:

1. Дослідження конституціоналізму як ідеології, що містить у собі й історичну компоненту (історію держави і права). Дослідження історії державності в Конституції України та порівняння змісту Конституції України у цьому плані з конституціями інших, зокрема сусідніх з Україною, держав.

2. Дослідження окремих проблем і періодів історії держави і права України відповідно до концепції багатодержавності українського народу.

\section{Література:}

1. Бездержавність (бездержав'я, недержавність) // https :/histua.com.

2. Бордюгова К., Богдан Д. Значення преамбули як складової частини Конституції України // UPL : https://law.univ.Kiev.ua.

3. Бориславський Л. Юр значення преамбули Конституції України // UPL : radnuk.info/home/24237-2013-05-14-18-03-32.html.

4. Гончаренко В. Д., Срмолаєв В. М., Рум'янцев В. О. Історія держави і права України : навч. посіб. Харків, 2013. 704 с.

5. Держава // Велика україн. юридич. енциклопедія. У 20 т. Т. 3. Харків, 2017. С. 89-92.

6. Жива конституція // UPL : htts://uk.wikipedia.org.

7. Канищев Г. Ю. Государственное управление в Украине: проблемы исследования // Матеріали VIII Міжнарод. наук.-практ. конф. «Людина, культура, техніка в новому тисячолітті». Харків, 2007. C. 48-49.

8. Конституция Латвии // База даних «Конституции государств (стран) мира» // UPL : wordconstitutions. ru.

9. Конституція України // UPL : https://urist-ua.net.

10. Конституция Хорватии // База даних «Конституции государств (стран) мира» / UPL : wordconstitutions. ru.

11. Петришин О. В., Погорілко В. Ф. Науково-практичний коментар до Конституції України // UPL : https://www.twirpx.com/file/148284. 
12. Про відзначення 22-ої річниці Конституції України. Указ Президента України № 91/2018. // UPL : www. president.gov.ua/documents/912018-23890.

13. Про вищу освіту: Закон України від 1.07.2014 № 1556-VII // База даних “Законодавство України»/BР України. UPL : http: zakon0rada.gov.ua/laws/shov/1556-18.

14. Про правонаступництво України: Закон України від 12.09.1991 № 1543-XII // База даних “Законодавство України»/BP України. UPL : http: zakon0rada.gov.ua/laws/shov/1543-12.

15. Стан юридичної освіти в Україні. Аналітичне дослідження за результатами освітніх вимірювань. Київ, 2018. 168 с.

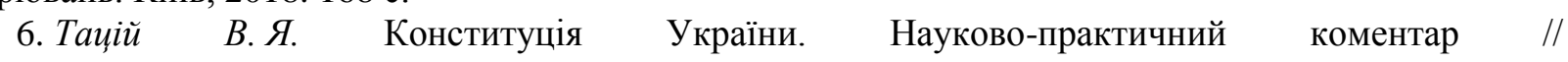
UPL : https://www.twirpx.com/file/124691.

7. Шляхтун П. П. Конституційне право : словник термінів. Київ, 2005. 566 с.

\section{Grygory Kanischev}

\section{LOGIC OF TEACHING HISTORY OF STATE AND LAW IN ACCORDANCE WITH THE CONSTITUTION OF UKRAINE}

History of State and law of Ukraine can be considered as one of the leading academic disciplines to modern lawyers because its purpose is to familiarize professionals with the historical experience of the development of statehood and the territory of modern Ukraine that directly or indirectly impact on the current status and the quality of the public authority in our country, on the relationship between the State and citizens, on the situation in Ukraine in the international arena, its image in the world, etc.

Great value for the teaching and study of history of State and Law of Ukraine have changes that have been happening lately in higher legal education in our country. Besides necessary legal skills and knowledge, present-day and future lawyers have to understand the nature of law and the philosophy of human rights, the role of the bureaucracy in the functioning of the State organized by the society, the mechanism of distribution of public authorities, as well as to understand the ways of development of the State and its transition from a developing country to a developed country. The role of history of State and Law of Ukraine here is mapping the processes of historical evolution of relationships between the human and the State on the modern Ukrainian territory. This includes compliance with State rights, in particular political struggle of people for their rights in both peaceful and violent way (through an armed revolt against the authorities) etc. In this connection, educational courses and researches on the history of State and Law should pay much attention to the evolution of public authority as a result of the struggle of people for their rights.

Keywords: ideology, ideological diversity, views and beliefs.

\section{Григорій Каніщев}

\section{ЛОГІКА ВИКЛАДАННЯ ІСТОРІЇ ДЕРЖАВА І ПРАВА УКРАЇНИ ВІДПОВІДНО ДО КОНСТИТУЦІЇ УКРАЇНИ}


Історію держави і права України можна вважати однією з провідних навчальних дисциплін для сучасних юристів. Її метою є ознайомлення майбутніх фахівців із тим історичним досвідом розвитку державності та права на території сучасної України, що прямо або опосередковано впливає й на сучасний стан і якість публічної влади в нашій державі, на відносини між державою й громадянами, на становище України на міжнародній арені, її імідж у світі тощо.

Велике значення для викладання й вивчення історії держави і права України мають зміни, які останнім часом відбуваються у вищій правовій освіті в нашій державі. Ідеться про потребу для сучасних i майбутніх юристів на додаток до необхідних юридичних навичок і знань розуміти природу права та філософію прав людини, роль бюрократії у функціонуванні державно організованого суспільства, механізм розподілу публічної влади, а також розуміти шляхи розвитку держави та їі переходу від держави, що розвивається, до розвиненої держави. Роль історії держави і права України тут полягає у відображенні процесів історичної еволюції взаємин людини й держави на сучасній українській території. Це стосується дотримання державою прав громадян, зокрема політичних, боротьби людей за свої права як мирним так і насильницьким шляхом (через збройне повстання проти державної влади) тощо. Велике значення у зв'язку із цим, на нашу думку, має відображення у навчальних курсах i наукових дослідженнях 3 історії держави i права України еволюції публічної влади внаслідок боротьби людей за свої права.

Ключові слова: ідеологія, ідеологічна багатоманітність, погляди й переконання.

Kanischev Grygory - PhD in History, Associate Professor of the Department of Law of National Aerospace University "KhAI".

Каніщев Григорій Юрійович - кандидат історичних наук, доцент, доцент кафедри права гуманітарного факультету Національного аерокосмічного університету ім. М.Є. Жуковського «XАI».

e-mail:

Надійшла до редакції 04.12.2018. Розглянута на редколегії 18.12.2018.

\section{Рецензенти:}

Доктор філософських наук, професор кафедри філософії Національного аерокосмічного університету ім. М.Є. Жуковського «ХАІ» Кузнецов А.Ю.

Кандидат філософскіх наук, доцент, завідувач кафедри права Національного аерокосмічного університету ім. М.С. Жуковського «ХАІ» Селевко В.Б. 